Studia Anglica Posnaniensia 51/4, 2016

doi: 10.1515/stap-2016-0019

\title{
HETEROGLOSSIA AND FRAGMENTARINESS IN THE ABSENT THERAPIST BY WILL EAVES
}

\author{
WOJCIECH DRĄG*
}

University of Wroctaw

\begin{abstract}
In "Discourse in the Novel" Mikhail Bakhtin argues that heteroglossia - a diversity of voices or languages - is one of the essential properties of the novel. The distinct languages spoken by individual characters (referred to as "character speech"), he maintains, inevitably affect "authorial speech". In experimental fiction, where "authorial speech" is often eliminated altogether, one can speak of the most radical instance of novelistic polyphony. Whereas in The Sound and the Fury, The Waves and B.S. Johnson's House Mother Normal in place of the narrator the reader is presented with several parallel voices which offer an alternative version of some of the same incidents, Will Eaves's The Absent Therapist (2014) comprises 150 one- or two-page monologues, each of which is delivered by a different nameless speaker. The book, described by reviewers as an "experimental novella", a "miniature novel", and an "anti-novel", is devoid of any frame that would account for the coexistence of so many stories. The only interpretive clues are provided in the paratext: the title and the dedication from 1 Corinthians ("There are, it may be, so many kinds of voices in the world, and none of them is without signification"). They appear to invite the reading of the entire text as an amalgam of disparate (but also, in large part, desperate) voices united by their addressee - the figure of the therapist who is not there. The aim of the article is to examine Eaves's assemblage of voices and outline the tenuous relationship between the sections. The analysis of common themes and motifs that provide a degree of qualified unity to the book's multiple monologues is situated in the context of fragmentary writing (as practised, among others, by Burroughs and Barthes) and its postmodernist aesthetics of the collage.
\end{abstract}

Keywords: collage, experimental, fragmentary, heteroglossia, polyphony

Corresponding author: Institute of English Studies, Department of English Literature and Comparative Studies, University of Wrocław, ul. Kuźnicza 22, 50-138 Wrocław, Poland, email: wojciech.drag@uwr.edu.pl. 


\section{Introduction}

Among the six works shortlisted for the second edition of the Goldsmiths Prize - established in 2013 to "celebrate ... creative daring ... and to reward fiction that breaks the mould or extends the possibilities of the novel form" - was The Absent Therapist (2014) by a relatively little-known English novelist, poet, and creative writing teacher Will Eaves. The book's radically fragmentary form - an amalgam of 150 disconnected voices - and its brevity (just over a hundred pages) puzzled many reviewers and left them uncertain if that work should be qualified as a novel in the first place. Critics have referred to it as an "antinovel", a "random catalogue of twenty first century scenarios, queries, complaints and observations" (Quick 2015), an "experimental novella" (Woodhead 2014), "a book for want of a more precise term" (Lezard 2014), something in between poetry and a novel (Sweetman 2014), and a "miniature but infinite novel" (Kennard). For the purpose of this analysis - in line with the recent tendency to loosen the generic criteria for what constitutes a novel, as a result of which such works as David Mitchell's Cloud Atlas (2005) and J.M. Coetzee's Elizabeth Costello (2003) and Diary of a Bad Year (2007) have been accepted in that accommodating category - Eaves's work is treated as an experimental novel. The aim of this article is to examine The Absent Therapist's innovative structure as well as to assert the book's polyphonic nature. The resistance of its constituent parts to fully cohere and yield a unified meaning will be considered as a characteristic feature of the subtype of experimental fiction called fragmentary writing.

The Absent Therapist is divided into five chapters, each of which contains between twenty three and forty three unnumbered and untitled sections, whose length varies between a single line and two pages. The chapters, in turn, are both numbered and titled. All the titles - "The Absent Therapist", "Where Do You Get Your Tired Ears From?", "We Are Prey", "Radio Traffic", and "A Start in Life" - are passages or phrases which feature at some point in any given chapter. Each section takes the form of a monologue spoken by a different person. However, the kinds of speeches delivered by characters do not follow any pattern. Some of them read like self-contained "short short stories", others are completely incomprehensible - cryptic remarks deprived of any context or bits of overheard phone conversations. Certain sections appear to be addressed to a listening "you", whereas others resemble individual thoughts and philosophical meditations.

"There are, it may be, so many kinds of voices in the world, and none of them is without signification", reads the novel's epigraph from 1 Corinthians 14:10. The voices, indeed, do not seem to have much in common, in terms of social standing, education, profession, age, gender or ethnicity. The wide array of 
speakers includes such individuals as a literature student, a body-builder, a callcentre operator, a hat-knitter, a hotel supervisor, a police officer, a careercounsellor, an experimental psychologist, an actor, and a Jew-turned-Christian geologist. There are very few examples of individuals who could be grouped under a certain heading; the only ones that could are teachers and academics (most of them rather frustrated), loners, homosexuals, and civil rights activists. ${ }^{1}$ The first edition's blurb classifies them, rather vaguely, as voices of "sons and lovers, wanderers, wonderers, stayers, leavers, readers and believers". Perhaps the only feature that all the speakers share is having English as their mother tongue; the vast majority of them seem to come from either Britain, the US or Australia. ${ }^{2}$

\section{Heteroglossia}

The multiplicity and variety of voices contained in Eaves's novel makes it a fine example of Mikhail Bakhtin's notion of heteroglossia. In "Discourse in the Novel" (1982), Bakhtin coins this term and defines it as the novel's essential inclination to accommodate multiple and diverse languages and voices. Among them are "the languages of social groups and classes, of professional groups, of generations, the different languages for different occasions" (Dentith 1996: 35). Heteroglossia is meant to be a marker of the novel's "stylistic and linguistic variety, its openness to the world-in-process of the present" as opposed to the monologic structure of epic poetry (Dentith 1996: 46-47). Crucially, the voices embedded in the novel are to be democratically arranged; Bakhtin asserts that in genuinely polyphonic novels the voices are "independent" and "fully valid" not subordinated to the author's restrictive jurisdiction (Bakhtin 1984: 6). The autonomous languages spoken by individual characters affect - often "powerfully so", Bakhtin adds - the "authorial speech", or, in other words, the voice of the narrator (Bakhtin 1982: 315). In The Absent Therapist, where there is no framing device or overarching voice, "authorial speech" is eliminated altogether and the autonomy of individual speeches is complete. Therefore, Eaves's novel - alongside works such as B.S. Johnson's House Mother Normal (1971), Julian Barnes's Talking It Over (1991) and Love, etc. (2000), and Max Porter's Grief Is the Thing with Feathers (2015) - can be interpreted as a radical instance of heteroglossia. ${ }^{3}$

\footnotetext{
In many cases, the profession or social status of the speaker cannot be established on the basis of their brief monologue.

2 Chapter One features mostly speakers from the UK, the second chapter - from Australia, whereas Chapter Three is dominated by American voices.

3 What distinguishes The Absent Therapist from the other four books is its lack of a narrative focus. Whereas Johnson, Barnes, and Porter present the same event or story from the point of view of multiple characters, Eaves has his speakers comment on an array of unrelated
} 
The Absent Therapist reinforces its heteroglossia by eclectically appropriating numerous genres. In "Discourse in the Novel", Bakhtin speaks of genre incorporation as "the most basic and fundamental form for incorporating and organizing heteroglossia in the novel". He argues that the novel's accommodating nature manifests itself also in its capacity to integrate "various genres, both artistic (inserted short stories, lyrical songs, poems, dramatic scenes, etc.) and extra-artistic (everyday, rhetorical, scholarly, religious genres and others)" (Bakhtin 1982: 320-21). The 150 monologues which constitute Eaves's book contain a number of examples of both literary and "extra-artistic" genres. The most prominent genre in the first category is the short story, or when taking into account the brevity of its examples - what has been referred to as the "short-short story" or flash fiction (Ziegler 2014: xxvii). Among the instances of such micro narratives are accounts of an elderly woman's doomed pursuit of her gay neighbour (The Absent Therapist, 20), the underhand visa schemes of a "Wardour and Soho School of English" (The Absent Therapist, 77), and a young boy's ploy to hide the evidence of having drunk his parents' brandy (The Absent Therapist, 84). All of the above read like independent, selfcontained stories, which proceed from outlining the context of a certain situation to delivering a humorous (and often surprising) punch line. Several monologues conclude on an epiphanic note, with the speakers gaining a sudden insight into the situation they are recounting - redolent of the spontaneous secular revelations experienced by Stephen Dedalus and other Joycean Dubliners. Other monologues in the novel share some characteristics of the confession and the lament. ${ }^{4}$ The last text in The Absent Therapist, in turn, is a revisited memory of a seemingly insignificant incident in childhood, which, as the speaker concludes in retrospect, was an experience that made him or her a writer (The Absent Therapist, 110-12). Its theme and positioning invite the reader to consider the piece as set apart from the rest and as a potentially autobiographical commentary on the genesis of the book at hand. As for the "extra-literary" genres contained in Eaves's novel, there are examples of almost all of its subtypes listed by Bakhtin: "everyday" speeches (such as phone conversations or jokes), "religious" genres, for instance a sermon on Jesus meeting disciples after the resurrection (The Absent Therapist, 54), and "scholarly" discourses, such as a lecture on the future development of artificial intelligence (The Absent Therapist, 81).

situations.

4 One speaker's complaint about the weather ("end-of-the-world wind and rain") and floods in the West Country reads like an allusion to Coll, Gyb and Daw's complaints at the beginning of the Second Shepherds' Play. 


\section{Civilisation and its discontents}

What persuaded most critics to accept the status of Cloud Atlas or Barnes's A History of the World in $101 / 2$ Chapters (1989) as novels was the recurrence of motifs and themes that grant their disparate parts (recounted by distinct narrators and populated by different characters) a degree of unity. The qualified cohesion of The Absent Therapist is secured through several common themes, cross-references between sections, and paratextual elements. Arguably, the dominant theme of Eaves's novel are unhappy lives, marred by financial instability, disease or loneliness. One narrator confesses, "I earn 400 pounds a week before tax, working anti-social hours to get a better rate. I have a wife and kids to support" (The Absent Therapist, 13); another complains, "One day I'd like to see London, go there. I've got to get some money together, first. That's what I need. I'm so fuckin' poor" (The Absent Therapist, 14-15). More dramatically, one section takes the form of a prayer of parents asking for their children not to be deported back to Burundi. Elsewhere, a sick man talks about his hope for a miracle recovery, while another man, suffering from cancer, wonders about feeling hungry despite having only half a stomach. The Absent Therapist contains several sad admissions of loneliness: "I have been on my own for days now, looking out of these windows, rubbing my eyes, wondering if I ever had plans for a life like this" (The Absent Therapist, 47); "I don't have anyone to tell this to" (The Absent Therapist, 85). Several narrators allude to traumatic experiences which continue to haunt them. A middle-aged social activist reveals the tragic source of her determination to act (and the feeling that she has nothing to lose): "my daughter was killed by a drunk and my son raped on a St Louis wharf, so I don't care" (The Absent Therapist, 54). Another speaker admits their inability to recover from the unspecified trauma: "The balm of consolation is too strong for some. Its most powerful ingredient is not the emollient lie that time heals, but the far more astringent perception that, whether we heal or not, the wound was deep and real and ours" (The Absent Therapist, 106).

Another prominent theme of The Absent Therapist is the annoyance and frustration about various aspects of everyday life. One of the most irate voices is that of an academic ranting about the complacency and narrow-mindedness of American society:

You know they've done tests on depressed people, people like me who are depressed by people like you, and you know what they found? People who are depressed are the realists. We give a speech, write an article, we know we're fucking losers and half the audience is bored and the other half are pissed off in some private, resentful way, think they can do better. You get up, full of fucking can-do and clap your hands while your pastor fucks little black boys and you say 
fuck Islam, fuck everyone, fuck the gays, fuck the free press, fuck it all just give me my fucking donuts and insurance. And I'm the baby-betraying coward. Because I don't shoot doctors. You're fucking insane.

(The Absent Therapist, 68)

On a related note, another speaker complains about their colleague's casual racism. Others express their irritation about rudeness, silly fashions, and clichéd expressions heard on public transport (for example, "a totally residential area", The Absent Therapist, 17). In several cases, anger is directed at a specific group of people, such as shopkeepers, waiters or evangelical Christians (too smug).

Quite a few sections address sexuality, but in most cases rather comically. One speaker recounts the following anecdote: "[My gay friend] told me a wonderful story once about some man who came round for sex and said, 'Give me a blow job, then.' And Terry said, 'That's not very romantic,' and the man sighed and said, "All right. Give me a blow job in the rain"" (The Absent Therapist, 9). In his review of the novel, Nicholas Lezard cites this passage as an encapsulation of Eaves's "particularly wry, or perhaps dry, sense of humour" (Lezard 2014). ${ }^{5}$ In another section, a police officer tells an anecdote about visiting an elderly lady and politely pointing out to her that neighbours have complained about the noise that she makes during sex. The embarrassing scene concludes with her disarming admission that she produces the contentious sounds while masturbating (The Absent Therapist, 48-49). Elsewhere, a boy walks into his older brother's room and finds him "wanking with another boy" (The Absent Therapist, 85). Characteristically, most of the sexual activities which are mentioned are those associated with non-heterosexual or nonstandard practices.

Although finding an overarching theme that would embrace all of the 150 monologues that constitute the novel is not possible, it could be argued that The Absent Therapist is dominated by voices that express various sorts of discontents bred within affluent Western societies. Instead of success stories, speakers mostly offer accounts of their everyday struggles and predicaments. Even if they do not complain about their own lives, they give vent to irritation or anger about the many shortcomings of the people around them. The idea that the general sense of frustration might serve as a common denominator of the multiple sections is intimated by the title of the book. The title phrase appears in one speaker's description of an awkward conversation with his "troubled" friend in a gay club in London. When the narrator attacks Owen for his irresponsible behaviour, he immediately regrets: "I realised he didn't have anyone to talk to .... it occurred to me that Owen had been addressing an ideal

5 This kind of deadpan humor is also reminiscent of Richard Prince's series of Jokes paintings. 
person, a sort of absent therapist, and I felt sorry for him" (The Absent Therapist, 28-29).

Several critics have commented on the title as a significant interpretive clue. Anna Aslanyan (2014) maintains that "the therapist of this novel's title is an ideal listener, someone whose ears ... are capable of hearing things", whereas Patricia Duncker (2014) states that "the absent therapist is the listening reader". If the reader is meant to occupy the position of Owen's interlocutor, the person who listens because nobody else will, it follows that they may also be expected to feel "sorry" for the novel's unfortunates. The reader would then be positioned as superior to the frustrated speakers in the same way that a therapist is superior to the patient who turns to them for help. That kind of reader-speaker relationship is by no means the dominant one throughout the novel. There is a passage in The Absent Therapist in which an older woman talking about living far away from her husband interrupts her story and says to an unspecified listener: "You're Mr Lucky ain't you? Mr Lucky Lucky" (The Absent Therapist, 76). She implies that the inexperienced or ignorant listener is in no way justified to pass judgement on her choices. That is surely no way to address a therapist figure. Although in the case of most monologues the reader's empathetic, or perhaps even sympathetic, response seems legitimate; the idea that they are veiled cries for help of those who have no one to hear them out cannot be defended. Likewise, the notion of therapy itself - or, more precisely, the Freudian conception of talking cure, according to which the articulation of a painful experience helps to integrate it with one's life-narrative and has a capacity for healing - is undermined in a previously cited passage, in which one of the speakers rejects "the balm of consolation" and asserts that wounds are "deep and real" (The Absent Therapist, 106).

\section{Harmony or cacophony?}

Leo Robson offers an alternative interpretation of the title phrase. He argues that "Eaves's idea of an absent therapist points partly to his own novel's lack of a narrator and partly to the role of gentle ushering played by a certain kind of novelist". For Robson, the "absent therapist" is not so much the reader as the author himself, who addresses the reader under the guise of one of the speakers: "I didn't have an identity and I didn't want one. I was neither boy nor girl, male nor female. I was just a pair of eyes, a nose, some ears. Receiving the world, the brilliant blue sky, people talking above me" (The Absent Therapist, 37). "That's Eaves", the critic announces, "ears pricked, mouth closed" (Robson 2014). The seeming absence can therefore be seen as a novelistic strategy, which relies on listening and absorbing the surrounding voices, while withholding the temptation to explain. According to Robson, Eaves subscribes to the notion of a novelist as 
"a conductor, a medium, at once intuitive and impersonal, receding from the stage to let the characters and reader work things out between themselves". The metaphor of the conductor is suggested also by Aslanyan, who calls the novel "a beautifully complex choral work", where everything is meticulously orchestrated and "every comma is vital for the flow to run as it does" (Aslanyan 2014).

What Robson's and Aslanyan's musical parallels ("conductor", "choral work") convey is the sense that the author is entirely in control of the meaning and that the multitude of fragments ultimately constitutes a coherent whole. The room for the reader "to work things out" for themselves seems to be an invitation for the reader to put the jigsaw puzzles in the pre-arranged order or crack the code, which makes everything fall into place. This may sound like an achievement - weaving a solid quilt out of a number of disparate patches - but I would argue that The Absent Therapist is not that kind of a novel. If it were, the earlier asserted polyphony would be a mere semblance of independent voices, subjected in fact to the single controlling voice of the author-orchestrator. Interestingly, Robson concedes that himself when he notes that "Eaves is careful to stop the signification of individual voices from building to a whole" so that, ultimately, it "stays a cacophony" (Robson 2014).

A good illustration of the novel's refusal to cohere is its use of red-herring links and cross-references. For instance, a section in the third chapter ends with the statement, "That's what I tell Darryl but he doesn't listen" (The Absent Therapist, 55). Two sections later a speaker named Darryl talks about a strange dream he once had. That, however, is as far as the link goes - a mere repetition of the unusual first name. Likewise, in the next chapter a female character named "Haneke" appears twice - this time three sections apart. One of the first monologues of Chapter Three takes the form of a sermon on Jesus' revelation to disciples on the way to Emmaus, while a speech eight sections later begins with the words: "Josephus speaks of an Emmaus about four miles from Jerusalem" (60). Yet again, the parallel does not extend any further. In his Guardian review, Nicholas Lezard comments on his experience of spotting such connections in The Absent Therapist: "Some of the voices and people recur, and for a while I thought I was going to have to keep track of them all - that there was an underlying order making this a very complex work indeed" (Lezard 2014). However, as he concludes, the links merely "tease [the reader] with the idea of larger significance" - a key to meaning and unity, which is tantalisingly "out of reach". Other critics have also pointed out the novel's "analysisresistant" and "elusive" qualities (Quick, Woodhead).

Part of the novel's elusiveness and resistance to meaning lies in its capacity to mislead and suggest self-contradictory interpretations. This strategy can be exemplified by juxtaposing two passages from different sections of The Absent Therapist, which sound like metafictional comments on the structure and 
ambition of the book and thus, in Lezard's words, "tease" the reader with the offer of a key to a "larger significance". In one of the fragments, an unspecified speaker remarks: "You must penetrate all of this drift and dreck to get to the soul of the building, to what it is thinking and saying, in many voices - the voices of everyone who has ever lived or stayed there, all of whom go on talking after they have moved on with a sort of calm but intangible insistence like the sound of a radio being reasonable in an empty room" (The Absent Therapist, 108). Those words could be interpreted as an illustration of the novel's policy of juxtaposing a wealth of disparate voices and an implication that the reader's task is to sieve the confusing "drift and dreck" of its surface structure and aim to reach its hidden but recoverable deep structure, which will yield the "soul" of the book. The point would be to understand what the novel is "saying, in many voices" (The Absent Therapist, 108). The passage suggests, then, that polyphony exists only at the surface level - the voices, once "penetrated", all have their origin in the same source and convey, essentially, the same message, which is an emanation of the novel's "soul".

In a different section, an academic praises a book of short stories in a way that could be interpreted as offering an alternative perspective on the structure of The Absent Therapist: "[The stories are] like bronze miniatures: small sketches of domestic living and discontent pressed into some harder surface. Everything is in close-up ... and then the camera pulls back and we see the characters as they really are, as we are, figurines in a landscape" (The Absent Therapist, 40). The image of individual sections as distinct miniatures indicates that, when juxtaposed, they are not going to consolidate into a seamless whole; rather, they are going to remain separate entities. Eaves's strategy of combining apparently incongruous parts (such as mini-lectures, distant memories and snippets of phone conversations) which - when considered together - assume a certain common denominator ("sketches of domestic living and discontent") is similar to the policy adopted by another fragmentary novelist Jenny Offill. In reference to her first book Last Things (1999), Offill said that "when you put things on the same plane, you start to see that they're not necessarily as far apart as they might seem" (Haas 2015). She quoted the Swiss writer Robert Walser, who had praised Paul Cézanne for his technique of "placing in the same 'temple' things both large and small", demonstrating the arbitrariness of the received notions of the important and the trivial (Haas 2015).

\section{In fragments we trust}

The democratic arrangement of disparate parts, alongside the previously asserted heteroglossia and resistance to a single meaning, is a characteristic of fragmentary 
writing. ${ }^{6}$ Its other common ingredients are non-linearity, lack of chronological order, metatextuality, as well as a frequent use of citations, repetitions, and lists. The lack of a cause-and-effect relationship between consecutive passages forces the reader to focus maximum attention on the scattered formal or thematic connections. Fragmentary literature can thus be seen as a writerly (scriptible) mode of writing, which Roland Barthes defines in $S / Z$ as a rejection of narrative conventions while granting the reader the autonomy to construct the plural meanings of the text (The Absent Therapist, 5). ${ }^{7}$

Such writing can be placed in the context of what Gerald Graff calls "modern experimental texts", which "having renounced story and narrative, depend much more heavily on the reader's ability to locate thematic propositions capable of giving their disjunctive, fragmentary, and refractory details some exemplary meaning and coherence". Graff notes that, in the absence of "a continuous story (or argument)", the "images and motifs" that constitute the text may have "little unity or relevance to one another apart from the abstract concepts they illustrate" (Graff 1979: 164-165). In a recent manifesto for brevity in literature Life Is Short - Art Is Shorter (2014), the author of Reality Hunger David Shields and Elizabeth Bookman celebrate works in which divergent elements are combined into a thematically coherent text. They call such works collages and contrast them with traditional narratives, which rely on the progression of the plot. Collage, in turn, "depends upon the orchestration of variegated materials - separated by white space and unconnected by plot - into theme" (Shields \& Brookman 2014: 161). Shields and Brookman invoke Picasso's remark - "A great painting comes together, just barely" - and argue that that is also precisely the point of every literary collage - to "come together, but just barely" (Shields \& Brookman 2014: 162). The separate parts are meant to combine and integrate, but not seamlessly, without renouncing their distinctness. ${ }^{8}$

The proliferation of fragmentary writing since the second half of the twentieth century can be attributed to a general wariness of totalising accounts and master narratives, which has been associated with a postmodern sensibility. Ihab Hassan asserts that "the postmodernist only disconnects" and therefore

6 Although the term has not received much attention in Anglophone criticism, it is a recognized category in French literary discourse, where it functions as écriture fragmentaire and has been applied to the works of Edmond Jabès, Pascal Quignard, Roland Barthes, and Maurice Blanchot.

7 Writerly works are also essentially polyphonic: "a galaxy of signifiers, not a structure of signifieds", without beginning or end. They can be accessed "by several entrances, none of which can be authoritatively declared to be the main one" (Barthes 1974: 5).

8 David Markson's fragmentary tetralogy inaugurated by Reader's Block (1996) also points to the analogy with collage in its recurrent metafictional commentary on its own structure: "Nonlinear. Discontinuous. Collage-like. An assemblage". 
"fragments are all he pretends to trust". 9 Since postmodernism is programmatically opposed to totalisation, it favours the techniques of "montage, collage, the found or cut-up literary object" (Hassan 1990: 19). Although those fragmentary strategies are not customarily classified as realist, William Burroughs argues that his "cut-up" technique is better suited to convey the experience of modern reality than "representational" art, as it is more akin to the way people perceive reality: "Take a walk down a city street and put down what you have just seen on canvas. You have seen a person cut in two by a car, bits and pieces of street signs and advertisements, reflections from shop windows a montage of fragments" (Burroughs 1993: 61). ${ }^{10}$ The belief in the fragment's capacity for adequately representing reality has also been declared by the narrator of B.S. Johnson's Albert Angelo (1964), who speaks of his "attempts to reproduce the moment-to-moment fragmentariness of life, [his] life, and to echo it in technique, the fragmentariness, a collage made of the fragments of [his] own life" (Johnson 1964: 169).

The Absent Therapist is, likewise, a fragmentary work that through its form conveys the sense of the fragmentariness of reality. Its focus, however, is not so much on expressing the multiplicity (and incongruity) of elements that constitute a self or an individual life, but rather on asserting the profusion of surrounding voices. Although some of the voices express similar discontents, they do not speak in unison, asserting their individuality and independence. The incomprehensibility of some of the sections, owing to their brevity, fragmentariness or the lack of any explanatory context, can be interpreted as an illustration of the limited means at people's disposal to hear the voices - and understand the problems - of other people. ${ }^{11}$ The novel's skilful oscillation between cohesion and disconnection, relevance and randomness, is the quintessence of the paradoxical politics of fragmentary writing - to place distinct elements alongside one another in a way that makes them cohere but preserves their separateness - to come together, but only barely.

9 The narrator of Donald Barthelme's short story "The Indian Uprising" articulates that sentiment when saying, "Fragments are the only forms I trust" (Barthelme 1968: 157). This statement could serve as a motto of all fragmentary writing.

10 Although relevant to fragmentary writing at large, Burroughs's "cut-up" technique - with its greater reliance on the aleatoric and smaller, more fragmented components - is quite distinct from the method employed by Eaves.

11 In her review of the novel, Sophie Quick (2015) argues that "it is pervaded by a sense of wonder" and by the conviction that "other people are an endless source of mystery". 


\section{REFERENCES}

\section{PRIMARY SOURCES}

Bakhtin, Mikhail. 1982. Discourse in the novel. In Michael Holquist (ed.), The dialogic imagination, 259-422. Trans. Caryl Emerson. Austin: University of Texas Press.

Bakhtin, Mikhail. 1984. Problems of Dostoyevsky's poetics. Trans. Caryl Emerson. Minneapolis: University of Minnesota Press.

Barnes, Julian. 1989. A history of the world in 10 1/2 chapters. London: Jonathan Cape.

Barnes, Julian. 1991. Talking it over. London: Jonathan Cape.

Barnes, Julian. 2000. Love, etc. London: Picador.

Barthelme, Donald. 1968. Unspeakable practices, unnatural acts. New York: Farrar, Strauss and Giroux.

Barthes, Roland. 1974. S/Z: An essay. Trans. Richard Miller. New York: Hill and Wang.

Child, Clarence Griffin (ed.). 1910. The second shepherds' play, Everyman and other early plays. Boston/New York: Houghton Mifflin Co.

Coetzee, J.M. 2003. Elizabeth Costello. New York: Viking.

Coetzee, J.M. 2007. Diary of a bad year. London: Harvill Secker.

Eaves, Will. 2014. The absent therapist. London: CB Editions.

Johnson, B.S. 1964. Albert Angelo. London: Constable.

Johnson, B.S. 1971. House mother normal. London: William Collins.

Markson, David. 1996. Reader's block. Normal: Dalkey Archive.

Mitchell, David. 2005. Cloud atlas. London: Hodder \& Stoughton.

Porter, Max. 2015. Grief is the thing with feathers. London: Faber \& Faber.

Offill, Jenny. 1999. Last things. New York: Farrar, Straus \& Giroux.

\section{SECONDARY SOURCES}

Aslanyan, Anna. 2014. The overhearing. In 3:AM Magazine, 21 August 2014.

http://www.3ammagazine.com/3am/the-overhearing/ (date of access 14 March 2016).

Burroughs, William. 1993. The fall of art. In The adding machine: Selected essays, 60-64. New York: Arcade.

Duncker, Patricia. 2014. Back cover endorsement. In The absent therapist. London: CB Editions.

Dentith, Simon. 1996. Bakhtinian thought: An introductory reader. Abingdon: Routledge.

Graff, Gerald. 1979. Literature against itself: Literary ideas in modern society. Chicago: Chicago University Press.

Haas, Lidija. 2015. Jenny Offill: Life after Dept. of speculation: The underdog persona's not going to fly any more. In The Guardian, 28 February 2015. https://www.theguardian.com/books/2015/feb/28/jenny-offill-dept-speculationunderdog-personas-not-going-to-fly-any-more-interview (date of access 14 March 2016).

Hassan, Ihab. 1990. Pluralism in postmodern perspective. In Matei Calinescu \& Douwe Fokkema (eds.), Exploring postmodernism: Selected papers presented at a workshop on postmodernism at the 11th International Comparative Literature Congress, Paris, 
20-24 August 1985, 19-40. Amsterdam: John Benjamins.

Johnson, B.S. 2004. Albert Angelo. Omnibus by B.S. Johnson. London: Picador.

Kennard, Luke. Front cover endorsement. In The absent therapist. London: CB Editions.

Lezard, Nicholas. 2014. The absent therapist by Will Eaves - Review. In The Guardian, 11 February 2014.

https://www.theguardian.com/books/2014/feb/11/absent-therapist-will-eaves-review (date of access 14 March 2016).

McHale, Brian. 1989. Postmodernist fiction. London: Routledge.

Quick, Sophie. 2015. The absent therapist: 150 beginnings to 150 novels. In The Australian, 12 September 2015. http://www.theaustralian.com.au/will-eaves-absent-therapist-review (date of access 14 March 2016).

Robson, Leo. 2014. How to disappear completely: The novel as an exercise in self-scrutiny. In New Statesman. 16 October 2014. http://www.newstatesman.com/culture/2014/10/how-disappear-completely-novelexercise-self-scrutiny (date of access 14 March 2016).

Shields, David \& Elizabeth Bookman. 2014. Life is short - Art is shorter: In praise of brevity. Portland: Hawthorne.

Sweetman, Simon. 2014. Will Eaves: The absent therapist. In Off the tracks, 31 March 2014. http://offthetracks.co.nz/will-eaves-the-absent-therapist/ (date of access 14 March 2016).

Walser, Robert. 2002. Thoughts on Cézanne. In Robert Walser, Selected stories, 189-192. New York: New York Review Books.

Woodhead, Cameron. 2014. Short reviews of fiction by Will Eaves, Sarah Moss, Lee Child, Philippa Gregory. In Sydney Morning Herald, 5 September 2014. http://www.smh.com.au/entertainment/books/short-reviews-of-fiction-by-will-eavessarah-moss-lee-child-philippa-gregory-20150831-gjbjdy.html (date of access 14 March 2016).

Ziegler, Adam. 2014. Introduction. In Adam Ziegler (ed.), Short: An international anthology of five centuries of short-short stories, prose, poems, brief essays, and other short prose forms, xxv-xxiv. New York: Persea. 